Orbis Tertius

ISSN: $1851-7811$

publicaciones@fahce.unlp.edu.ar

Universidad Nacional de La Plata

Argentina

\title{
Mirta Zaida Lobato, Infancias argentinas. Buenos Aires, Edhasa, 2019, 200 páginas
}

\author{
Batticuore, Graciela \\ Mirta Zaida Lobato, Infancias argentinas. Buenos Aires, Edhasa, 2019, 200 páginas \\ Orbis Tertius, vol. 25, núm. 31, 2020 \\ Universidad Nacional de La Plata, Argentina \\ DOI: https://doi.org/10.24215/18517811e160
}

Atribución no comercial compartir igual (CC BY-NC-SA) 4.0 


\section{Mirta Zaida Lobato, Infancias argentinas. Buenos Aires, Edhasa, 2019, 200 páginas $^{1}$}

Sabemos, los que nos dedicamos a leer o a escribir literatura, que la originalidad o el valor de una obra está dado sobre todo por su forma. Cómo hablar y decir algo nuevo acerca del amor, de la vida, de la muerte, de la madre, del miedo, se pregunta un escritor o una escritora cualquiera, cuando se sienta a escribir y explora, en la forma narrativa o poética, una respuesta. La historiadora Mirta Lobato también parece haberse enfrentado a este desafío crucial cuando se decidió a escribir su libro más reciente, en cuyo prólogo plantea una pregunta inefable: ¿qué es la infancia? Creo que uno de los intentos de dar respuesta a semejante interrogante se expresa en la forma que eligió para componer una obra que no sólo ofrece saberes y conocimientos sobre el tema sino que depara a los lectores emociones intensas. Cito a Lobato en el prólogo a Infancias argentinas:

[este] es un libro de imágenes con palabras, con palabras de investigadores, de poetas, con la voz de los medios de comunicación. (...) Está armado como si fuera un puzzle, un rompecabezas, porque los lectores y lectoras pueden restaurar las piezas, las imágenes, para pensar su propia experiencia y la de la sociedad en su conjunto (p.).

Leo las páginas que siguen, leo en el orden previsible de las páginas en sucesión y después vuelvo por aquí o por allá en el volumen, a detenerme en una imagen en particular, en un recorte singular del "rompecabezas". Experimento el libro como un objeto que me deja ver hacia atrás en el tiempo y en presente, me invita a pensar de la manera que más me gusta, o sea a pensar sintiendo, tratando no sólo de entender eso de lo que me habla la obra sino de comprender lo que leo-veo, capto en este libro. Entonces me hago una pregunta: ¿por qué una historiadora elige este camino para abordar un tema tan grande, inmenso, podríamos decir, nada menos que la infancia? Un tema con tanto archivo y tanta historia nacional y universal para desentrañar. Tanteo mentalmente algunas respuestas, por ejemplo que Mirta Lobato desestimó la entrada monológica de una voz autoral en esta obra, prefirió dar paso a la polifonía de voces, de imágenes y de opiniones de especialistas diversos, lo hizo acaso para desjerarquizar los motivos ligados al mundo de la infancia, para incorporar más experiencias e intervenciones variadas, para atrapar lo que a primera vista parece inasible. Eso de lo que todos sabemos mucho y nadie puede a ciencia cierta ofrecer definiciones tajantes: la infancia. Pienso también que la autora confió en el poder de transmisión que tienen las imágenes, puso en pie de igualdad la información visual y discursiva, en otras palabras, apostó a la pregnancia de una multiplicidad de estampas de niños y niñas de toda clase y de todas las clases sociales que van escandiendo la obra ante los ojos de los lectores y las lectoras, dando pie a las interpretaciones, los testimonios de corte historicista, literario, filosófico, artístico, sociológico, que se entrelazan página tras página para montar el caleidoscopio de "las infancias argentinas". Observo también que acudió a los archivos públicos, provinciales, a los privados, a los familiares, a los personales, con una confianza y una entrega que no elude la puesta en valor de lo cotidiano, la pequeña historia o la microhistoria, incluso la historia afectiva que se hace palpable y vívida en estas páginas e irrumpe sigilosa, oportuna, para ilustrar diversas cuestiones.

Creo que la apuesta a la pluralidad es un intento por captar no sólo la condición inefable de la infancia sino su variabilidad, lo disforme, la desigualdad de "las infancias argentinas", que sin dudas son muchas a lo largo de la historia y dependen de contingencias individuales, sociales, culturales, políticas, de época. Las infancias 
varian con el tiempo, esta es una de las tesis articuladoras del libro; las infancias y sus representaciones varían también, así como cambian las costumbres, las modas culturales, las sociedades y, por eso, agregaría yo, la infancia suele dar lugar a la nostalgia, cuando no a la melancolía, suele dar lugar a la memoria, a la historia, también a la ficción, como lo demuestran las voces de unos cuantos personajes literarios que intervienen a lo largo de la obra para recrear mundos, para evocar alegrías o traumas infantiles. Así vemos aparecer, en diversos recortes del puzzle, a "la niña de la calesita" en un relato de Silvina Ocampo; a "la niña rubia" de un poema de Alfonsina Storni; a "los niños abandonados" que el corazón de Raúl Gonzalez Tuñón vislumbró en la Buenos Aires de 1920; a otra niña que padece las penurias de la clandestinidad de sus padres durante la última dictadura militar, en La casa de los conejos de Laura Alcoba; así escuchamos también la voz estremecedora del narrador de El niño proletario de Osvaldo Lamborghini, que irrumpe en este libro como un grito de alerta, una llamarada incandescente que viene a desbaratar cualquier imaginario inocente o idílico de la infancia, demuestra que ella que puede ser también cruel, atroz, desoladora.

Estos cuadros e imágenes literarias nos recuerdan que la infancia es una experiencia intensa de la vida o más bien indeleble, eso que regresa siempre en la sensibilidad del adulto como una suerte de presente perpetuo, aunque no sea siempre un paraíso lo que vuelve sino también, a veces, un infierno. La niñez como trauma o infierno, sí. Y de eso dan cuentas diversas entradas, imágenes, capítulos del libro que ponen de relieve lo que podríamos llamar las infancias tristes o desgraciadas, las que son parte de una historia no sólo pasada y nacional sino universal y persistente. Basta pensar en los niños de las migraciones forzadas que escapan del hambre o de la guerra en una parte del mundo, para llegar penosamente a otras donde son expulsados o dejados afuera de las fronteras, en situaciones desesperantes. Pero en verdad no hace falta ir tan lejos en la geografía o en el tiempo: basta abrir los periódicos y leer las noticias locales. Recordar, por ejemplo, que mientras se presentaba el libro de Mirta Lobato en el Museo Parlamentario, entrado mayo de 2019, por esos mismos días nos enterábamos espantados que en la localidad de San Miguel del Monte cuatro niños argentinos perdían la vida dramáticamente adentro de un auto, iban huyendo, en una cacería imprevista, de la policía que los perseguía a tiros y no los acribilló porque se estrellaron antes. Los chicos murieron en pleno desflorar de la vida de un modo espeluznante.

Creo que el libro que hoy presentamos se comunica también con estas y otras realidades desoladoras de la vida social, cultural y política del país, a la que la niñez no escapa ni escapó jamás. Y lo hace a través de una mirada incisiva que se despliega, no se concentra en un solo asunto, en una sola problemática, en una sola época, en una sola perspectiva sino que se abre y se extiende a diferentes puntos de vista, para visualizar el vasto panorama de la infancia nacional. Así aparecen en el libro, junto a los escenarios felices que la niñez puede o ha podido deparar a muchos de nosotros (infancias de circo, vacaciones, disfraces, bicicletas, olor a pan casero, entre tantas reminiscencias posibles que sabemos), otras infancias: la de los niños migrantes que transitaron el destierro alguna vez, la de los niños de la guerra, la de los niños desaparecidos durante la última dictadura militar, la de otros niños en la pobreza, los niños marginales de las infancias piqueteras: esos que de pronto son testigos involuntarios del corte de una ruta o miran desde la banquina cómo humea un neumático entre la multitud. También los niños trabajadores de todas las épocas se hacen presentes en este libro: el canillita y el lustrabotas, las niñas obreras de las fábricas, las que limpian en las casas antes de cumplir la mayoría de edad, los niños indígenas del interior del país.

Esas realidades infantiles evocadas en el libro de Lobato nos hacen pensar en el revés de todos los convencionalismos, en el revés de los clishés normalizadores de las infancias burguesas, de las perspectivas oficialistas en diferentes épocas, nos invitan también a reflexionar por fuera del libro, en un plano que atañe a la vida - tal como lo hacen los buenos libros-, por ejemplo en los niños sin padres, en los niños de la pelota de trapo (capturados en un fotograma que se reproduce en la obra), en el vaso de leche que no espera a la vuelta del colegio, en los niños sin techo, en las casas devastadas por las inundaciones, en las infancias maltratadas, en la casa cuando no es ni hogar ni amparo para una familia, en las infancias torturadas, en los niños cuando no son "los únicos privilegiados" sino los olvidados del sistema o los que quedan al margen de "la 
protección” gubernamental que a fines del siglo XIX llevó, por fin, a los legisladores socialistas, anarquistas y los comunistas a reclamar una legislación adecuada. Son las infancias que habían quedado a la intemperie, podríamos decir, y que las declaraciones oficiales de los Derechos del niño que se pronunciaron en Ginebra, en las Naciones Unidas, a comienzos del siglo XX, intentaron rescatar.

En su conjunto, este libro ofrece un panorama sobre las infancias maltratadas y las felices, muestra su "convivencia" en el pasado y en la actualidad, como advierte Mirta Lobato en el prólogo. Y de ese modo busca despertar la mirada sobre estos asuntos humanos, bajo la perspectiva interdisciplinaria de un conjunto de especialistas que abonan la gran temática de la infancia desde diferentes enfoques y sensibilidades. Son ellos Andrea Andújar, Luciana Anapios, Diego Armus, María Marta Aversa, Dora Barrancos, Gabriela Barolo, Cecilia Belej, Ana Broitman, Paula Bontempo, Lila Caimari, Hernán Camarero, Isabella Cosse, María Cristina Erbaro, Silvia Finocchio, Federico Lorenz, María Fernanda Lorenzo, Ricardo Hernán Martínez Mazzola, Enrique Mases, Karina Ramacciotti, Ana Lía Rey, Ana María Rigotti, Selene Román, Ludmila Scheinkman, Juan Suriano, Sandra Szir, Lizel Tornay, Mirta Varela, Laura Vázquez.

En otro plano, la lectura de Infancias argentinas me remitió a un ensayo ya clásico sobre la fotografía. Me refiero a La cámara lúcida, de Roland Barthes, el último ensayo que escribió el autor antes de morir. Fue en 1980, pocos años después de publicar Barthes por Barthes y el Diario del duelo, cuando ya había perdido al gran amor de su vida, la madre. Se puede pensar, acaso, que Barthes compuso el libro intentando recuperarla, en la memoria de escritura, en las imágenes del recuerdo, buscando una fotografía que se la trajera de nuevo, que le devolviera de ella un gesto personal e íntimo capaz de poner otra vez a la madre, como siempre lo había estado en su vida, bajo la propia mirada. Mientras el autor analiza el poder de las imágenes en la historia de la fotografía, y mientras nos enseña la diferencia entre el studium y el punctum en una foto (recordemos que dice Barthes que el punctum es algo así como un fogonazo en la representación visual, que nos intercepta, nos cautiva y le habla directo al corazón), llega el momento del relato en que encuentra, por fin, lo que buscaba con afán: hurgando en los álbumes familiares Barthes da con una foto de la madre que expresa mejor que ninguna otra lo que él llama, literalmente, "su alma". Es una foto de infancia la que encuentra el autor - el hijo- en el archivo familiar, una foto de la madre niña donde despunta el gesto fortuito que la singulariza. Esta es la única foto que Barthes decide no compartir con los lectores, aunque se detiene en ella para describirla: morosa y amorosamente pero se reserva para sí la estampa, prefiere dejar intacto ese registro visual, la representación material en el impreso que tiene entre las manos. Recordé personalmente a este Barthes mientras leía Infancias argentinas, quizá porque la foto de la madre con el hijo se hace presente varias veces aquí también, de una manera a la vez literal y metafórica, incluso, tal vez, emblemática.

Tal vez era inevitable ese registro, podríamos decir. Hay madres en las infancias no sólo argentinas. Hay nodrizas también. Hay maestras. Hay hermanas. Hay amigas. A veces incluso hay novias. Hay mujeres. ¿Cómo concebir una infancia sin madres?, ¿cómo concebirla sin mujeres? Sería imposible, en el pasado tanto como en el presente, aún cuando la maternidad tenga, también, una historia que muta y seguirá variando con el tiempo. En algunas entrevistas que dio Mirta Lobato con ocasión de la salida de este libro, decía que empezó a pergeñarlo a partir de una colección de imágenes de madres con sus hijos. Es sabido que la historiadora se dedica hace años al mundo del trabajo, la historia obrera y los estudios de género. Y que viene trabajando junto con su equipo de investigación, en la elaboración de un archivo de imágenes visuales que creo excede en mucho las fotografías que logró ingresar a este libro sobre la infancia. En la tapa hay una imagen escolar, niñas dibujando con tizas la silueta del país sobre las baldosas agrisadas, una maestra que acompaña, gobierna el patio de la escuela, enseña. Vemos los guardapolvos sobre los cuerpos infantiles. La imagen propicia, entre otras, una pregunta fundamental que el libro multiplica: cómo o cuánto están mutando hoy las infancias argentinas pero, también, qué costumbres o prácticas de infancia y del pasado se conservan casi intactas hasta hoy. En este mundo actual, donde se dice que los derechos de los niños alcanzan la posibilidad de elegir incluso la identidad sexual, sabemos, por ejemplo, que hay todavía muchas más maestras que maestros en los patios de las escuelas y en las aulas, es decir, hay un predominio enorme de mujeres en el ámbito de la educación 
primaria. Fuera de las escuelas, las mujeres siguen dando batalla en la casa y en la calle, pidiendo el derecho a decidir sobre sus cuerpos, sobre la hora de la maternidad o sobre la elección de no ser madres, sobre la igualdad laboral, sobre el cupo femenino en los espacios de poder. Las niñas siguen jugando a las muñecas, cambiando vestidos, los varones juegan todavía con armas y con autos en los videojuegos. Quizá porque persiste la guerra en los imaginarios infantiles como una forma de dirimir las diferencias humanas entre los adultos, y porque en los campos de batalla donde se disputa el poder de las armas y los cuerpos sigue habiendo una mayoría de varones. Esta dimensión que también abre el libro invita a desmitificar, a cuestionar los estados de inocencia, las costumbres argentinas, a preguntarnos sobre el valor de la infancia, de la maternidad, sobre el rol de las mujeres, las relaciones de género y el compromiso social.

Entre todas las fotografías que conforman la galería de imágenes de este libro me detengo arbitrariamente en dos. Una es la de dos niños tobas que miran al fotógrafo como queriendo indagar la "otredad" que, para ellos, está del otro lado de la cámara, del lado del que observa atrás de la mirilla. Dos pares de ojos indígenas, dos niños de cara morena y guardapolvo blanco que nos miran de frente, azorados. Qué dicen estos ojos, cómo nos interceptan en un largo presente es posible preguntarse. Y contestar que esas miradas devuelven acaso al fotógrafo el gesto inquisidor de quien escudriña a esos mismos niños. Quiero decir que la foto registra una realidad que tiene derecho y revés: mientras miramos a esos chicos en el retrato en dúo, ellos miran a los curiosos desconocidos. Entre otras, esta foto forma parte de una búsqueda que el libro persigue: la de los archivos provinciales que dan cuentas de otras poses y cuadros de infancias argentinas que no son las porteñas. Esta a la que me refiero viene de Formosa. Hay otra, en esta misma línea que quiero imaginariamente compartir: la de un chico que carga sobre los hombros unas chapas acanaladas que serán el techo de su casa. "Pedro lleva chapas tras el temporal", así la tituló el fotógrafo Dani Yako, en 2009. El cuerpo doblado del niño define otra de infancia argentina que corre el riesgo de ser olvidada si las imágenes, las palabras y la historia no salen al rescate.

Un par de observaciones finales para terminar: 1) como Cortázar, que para contar una historia de amor eligió la rayuela, Mirta Lobato y colaboradores se entregaron a la magia de un juego para historizar la infancia; 2) pero la autora es una historiadora que prefirió esta vez abandonar la diacronía en el tratamiento de un tema, la voz monológica, el relato lineal, para optar por la forma narrativa del puzzle. Y en qué consiste este juego o qué ejercicio propicia, vale la pena preguntarse. Se trata de desautomatizar la mirada del observador, que escapa en el juego al orden previsible de las imágenes, de las cosas y del mundo, para darle a un niño o a un adulto la ocasión de concentrarse en cada una de las partes. El puzzle confía la suerte del conjunto, un poco, al azar, otro poco, a la intuición pero también a la mirada detallista, también al pálpito pero sobre todo a la perspicacia del ojo y a la dinámica de la prueba y el error, que implica encajar una pieza en un lugar que puede no ser el acertado para corregirse hasta dar en la tecla.

Cuando el jugador consigue armar su modelo (como Cortázar, otra vez, que no por casualidad escribió 62 modelos para armar), entiende el sentido y encuentra su objeto. En algo se parece un puzzle a otra clase de juegos que muchos probamos en la infancia: los Mil Ladrillos, los Rasti o también un pariente cercano con el que juegan las generaciones actuales, los Lego. Jugando con sus piezas se aprende, por ejemplo, que para armar un edificio son imprescindibles el techo, las ventanas, las puertas y cada uno de los ladrillos que conforman la maqueta final. Sin una sola de las piezas no es posible armar el conjunto. Infancias argentinas apela entonces a la misma pedagogía de los Lego y del puzzle, porque sin las intervenciones de cada uno de los especialistas convocados sería imposible ese friso emotivo y bien informado que forma el conjunto. Y sin embargo, leer este libro nos deja pensando que hay mucha más historia por escribir sobre el tema y por eso el libro es como un mapa virtual con postas y paradas que pueden abrirse y ampliarse. Quiero decir que este libro no tiene un final, sino que llama a otras voces y a otras miradas que sean capaces de capturar esa marca indeleble y a la vez inefable de la infancia que detenta constelaciones múltiples. De pronto, leyéndolo, me acordé por ejemplo de las canciones de infancia: la farolera, el arroz con leche, el saludo a la bandera, el arrorró en italiano que me cantaba mi madre. Pongo esas voces y otras tantas imágenes que vienen de recuerdos personales o colectivos, 
también, al fin de estos comentarios, para cerrar diciendo que Infancias argentinas ofrece no solo un saber sino también un sentir sobre el asunto al que se refieren sus páginas. Y esta doble impronta es ganancia.

\section{NoTAS}

1 Se publica la presentación del libro llevada a cabo el día 27 de mayo del 2019, en el Museo Parlamentario de la Ciudad Autónoma de Buenos Aires.

\section{BY-NC-SA}

